\title{
Assessment of Students' Perception of Dress Code in Tertiary Institutions in Nigeria: A Study of Federal College of Education Zaria.
}

\author{
Dr. Kayode Asaju \\ Department of Political Science, \\ Faculty of Humanities Management and Social Sciences, Federal University, P.M.B 1020, Wukari-Nigeria
}

\begin{abstract}
Indiscipline constitutes one of the major impediments to academic excellence in Nigeria. This study examines the reasons and consequences of student violation of the Dress Code in Federal College of Education Zaria. Both primary and secondary data were utilized and these data were qualitatively and qualitatively analysed to answer the research questions. Finding shows that the students' perception of the Dress Code was due to their family background and the influence of the school environment. The study also reveals that despite the high level of students' awareness of the Dress Code, and the efforts of the Students' Affairs Unit, Security Unit, and the lecturers to enforce the Dress Code, there is still a high rate of students' violation of the Dress Code. The reasons adduced for the above includes; haphazard implementation of the Dress Code by those responsible for the implementation, and lack of political-will on the part of the College management to ensure the full implementation of the Dress Code. The study therefore recommends among others that the College management should not interfere unnecessary in the activities of those shouldered with the responsibility of enforcing the Dress Code in the College. A symbiotic relationship between the College management is required to ensure the effective implementation of the Dress Code and other rules and regulations guiding the conducts of the students in the College.
\end{abstract}

Keywords: Discipline, Dress Code, Education, Indiscipline, School Discipline, Students,

Accepted Date: 22 April 2013

\subsection{Background to the Study}

\section{Introduction}

Education is one of the greatest investments any nation makes to assure her future in terms of economic, socio-cultural and political development. Its importance in translating the future of great nations cannot be overemphasized. That is why every government in our contemporary world makes it a fundamental obligation to provide education for its citizens. The Longman Dictionary defines Education as "the result of the teaching or the training of mind and character" Education apart from inculcating knowledge is also aimed at formulation of character. Education is the formulation of the human person in view of the person's final end and the dignity of the society. Education at all levels seeks to draw out the good potential in people, to replace error with truth, ignorance and incompetence with knowledge and competence. Furthermore, education leads to wisdom and discipline which constitute the foundation of human happiness.

Education all over the world is expected to produce effective, honest and disciplined citizens. However, discipline which is the hallmark of our educational system before could be said to be at its lowest ebb in many of our educational institutions today. Students Indiscipline manifest itself in different forms such as dishonesty, lack of respect and consideration for elders and constituted authority, rudeness, absenteeism, lateness to class, examination malpractices, drunkenness, drug abuse, sexual immorality, cultism among others.

Considering the present trend, it seems the educational system has virtually collapsed. Akinmade et al (1999) succinctly describe the situation thus:

Most government schools have no roofs, desk and in many primary, secondary schools, pupils have to sit on bear floors; equipment are lacking, while infrastructures are grossly inadequate. Good teachers are frustrated by the increasingly scarcity of teaching aids and equipments, as well as by poor salary and condition of service. Today, the rate of dropouts has sky rocketed among the youths. Many drop out of school, because parents are unable to cope with the increasing cost of education. The government, on its part, hardly does anything to care for the less privileged. The collapsed of the education system is also the collapse of value system. The craze now is for materialism and accumulation of material wealth at whatever cost. Good conscience has been thrown to the dogs and what matters is how wealthy one is. 
A recent manifestation of indiscipline which constitutes a serious malaise in our tertiary educational institutions in Nigeria is indecent dressing, especially among the female students. In the past, the act of indecent dressing among students of tertiary Institutions in Nigeria was not rampant especially higher Institutions in the north, including Federal College of Education, Zaria. It was in this perspective that the Dress Code was launched at the 2004/2005 matriculation ceremony of Federal College of Education, Zaria.

\subsection{Statement of the Problem}

Federal College of Education, Zaria is a teacher- training institute shouldered with the responsibility of training teachers that are capable and responsible for the moral upbringing of the younger minds. This might not be possible when the teacher- trainees are indiscipline and morally bankrupt in their thinking, behaviour, actions, and mode of dressing.

But in recent times, the rate at which indecent dressing is been perpetuated, especially among the female students of Federal College of Education, Zaria was at an alarming rate. This was so, despite the laid down rules that not only forbids indecent dressing in the College, but also stipulated punishments for offenders. The Rules and Regulations that relates to students mode of dressing are contained in Section 8 Sub Section 1 of the Student Handbook of the College.

Efforts were made by the security officers and staff of Student Affairs Office to enforce the Dressing Code as stated in the Student Handbook. However, most times there has been strong resentment on the part of the erring students which often degenerated into disagreement between these officers and the students.

Therefore, what could be responsible for this strong resentment by students? What are the consequences of this disruptive attitude or behaviour on academic excellence in the College? This disruptive behaviour also has its own consequence on the person perpetuating it, other students, lecturers and other staff of the College, the host community and the society at large. Thus, the questions are, were the students adequately informed or enlightened on the existing Dress Code in the College? What are the causes and factors responsible for the attitudinal dispositions of the students to the Dress Code?

\subsection{Objectives of the Study}

The major objective of this study is to examine the consequence of indecent dressing among students of Federal College of Education, Zaria.

The specific objectives include, to:

i. Establish the level of awareness of the existence of Dress Code in the College

ii. Identify the causes of indecent dressing especially among female students in the College.

iii. Examine the attitudinal disposition of the students to the Dressing Code in the College.

iv. Identify the various reasons for the attitudinal dispositions of the students to the Dress Code in the College

v. Examine the various consequences of these attitudinal dispositions to the students and academic excellence in the College.

\subsection{Research Questions}

The study was carried out to provide answers to these questions

1. Were the student's adequately aware of the Dress Code in the College?

2. What was the perception of the students of the Dress Code in the College?

3. What informed or influence their perception to the Dress Code in the College?

4. What are the consequences of the above to the students and the institution as a whole?

\subsection{Scope and Limitation of the Study}

The female students of the College constitute the major study focus of the study. The study specifically examined their compliance or otherwise within the College premises. The time frame of the study was from 2008- 2010. This was the period when the Dress Code was re- enforced in the College

1.6 Significance of the Study

There had been an outcry of moral decadence in most of our educational institutions and even in the society today. The rate at which girls dressed indecently in campuses availed them for sexual abuses or molestations. No wonder sexual gratification perpetuated in campuses was far more than that of the activities of the prostitutes in the hotels. This constitutes a social-malaise in the society today. Thus, there had been an outcry by parents and other concern stakeholders in the educational sector for a reorientation and enlightenment on the evils of this immoral behavior. This work is timely as it would fill- in -the gap in knowledge.

In realisation of the consequences of this malaise, the College launched the Dress Code during the 2005 students' convocation. (FCE, Zaria Annual Report, 2005). But enforcing this Dress Code has been a major problem due to students' resentment to it. The study is timely as it would reveal the various opinions or 
perception of the perpetrators of this behaviour. This will help the school management in adopting a workable and crisis-free strategy in addressing the problem of indecent dressing in the College.

The study will also be of benefit to other educational institutions trying to cope with the menace of indecent dressing. The findings of this study could help them in formulating policies that would help in solving the problem of indecent dressing, among others.

The study will also serve as a reference point for students and other researchers who will be interested in this subject matter.

\subsection{Definition of Terms}

Education: The Longman Dictionary (1995) defined Education as "the result of the training of the mind and character". Education in this work implied the training inculcated and imbibed by the students of Federal College of Education, Zaria to become professional teachers. It is the various curriculum and extra curriculum activities geared towards training the students as a professional teacher.

Dress Code: These are rules and regulations relating to students' mode of dressing within the campus of the College as contained in Section 2 of the Federal College of Education Students' Handbook. The Dress Code stipulated the kind of dresses that students of the College should not wear within the campus, especially to the class and the punishment to be melted out to offenders. The Dress Code forbids any student of the College from wearing the following dresses

Dresses that expose sensitive and vital parts of the body (e.g. slit Skirts, Body Hugs, Show-Me-Your-Back, Spaghetti etc.);

Dresses that does not cover the knees;

Dresses that are tight (e.g. Jeans, Skirts, Hip Star etc.) that reveals the contour of the body;

Dresses that are transparent and see-through dresses;

T-shirts with obscene captions;

Dresses that are carefree (e.g. Flying Shirt Collars, Unbutton Shirts etc)

Dirty rough or shabby dresses and appearance;

Dresses that does not distinguish between natural sexes of the wearers;

Plaiting or weaving of hair and wearing of earring by male students;

Wearing of dark glasses

Student's Disposition: This has to do with the way students of the College perceived the Dress Code, and whether the Dress Code was justifiable as moral law.

\subsection{Concept of Discipline}

\section{Literature Review}

According to Preston and Zimnerer (1968:349), discipline is "a behavior which is in compliance with agreed rules and regulations. It also involves the steps taken by supervisors to correct the actions of employees who violate the rules. Megginson $(1970 ; 276)$ on the other hand argues that real meaning of discipline is the instruction or training given to one. Even when discipline is punishment, it is punishment intended to correct wrong behaviors in individuals and train them to do the right thing.

Hermann and Hilgert (1974:276) gave a comprehensive and a working definition of discipline. To them, discipline is a state of affairs, a condition in an enterprise in which there is orderliness, in which the members of the enterprises behave sensibly, properly, responsibly and conducts themselves.

For the purpose of this research, discipline can be defined as a state of affairs of orderliness in which students conduct themselves according to the laid down rules and regulations of the College.

Discipline is considered good where the students exercise self-discipline. Discipline is bad when students follow or obey the rules reluctantly or deliberately violate them. For instance, the aim of this study is to examine the reasons why students obey or disobey the Dress Code as stipulated in the Student Handbook of the College. Poor discipline normally indicates the need for corrective actions, such actions aimed at eliminating undesirable behaviour in a student.

School discipline has two main goals; to ensure the safety of the staff and students and to create an environment conducive for learning. Serious students' misconducts involving violence or criminal behaviour defeats these goals and often makes headlines in the process. However, the commonest discipline problems involve non-criminal student behaviours. These less dramatic problems may not threaten personal safety, but they still negatively affect the learning environment. A vivid example is the indecent dressing among students in the various campuses of tertiary institutions in Nigeria. Disruptions interrupt lesson for all students, and distributive student lose even more learning time. Gottfredson and Gottfredson (1989:26) in their study observe that in six middle schools in Charleston, South-Carolina students lost 7,932 instructional days due to in school and out-school suspension in a single academic year. 
It is however important to keep the ultimate goal in mind while working to improve school discipline. Duke (1987:187) argued that the goal of good behavior is necessary, but not sufficient to ensure academic growth. Effective school discipline strategies seek to encourage responsible behaviour and it provides all students with a satisfying school experience as well as discourages misconduct.

In their study of government secondary schools, Gottfredson and Gottfredson (1989:189) identified the following school characteristics associated with school discipline problem; Rules were clearly perceived as unfair or inconsistently enforced; Students did not believed in the rules; Teachers and administrators did not know what the rules were or disagreed on the proper responses to students' misconducts; Teacher administration corporation was poor or the administration is inactive; Teachers tend to have positive attitudes; Misconduct was ignores ; and schools were large or lacked adequately resource for teaching. Duke (1988:187) in agreement with Gottfredson noted that orderly schools usually balance clearly established and communicated rules with a climate of concern for students as individuals. Small alternate schools often maintain order successfully with fewer formal rules and a more flexible approach to infractions than large schools typically have.

According to a growing number of literatures, the primary determinant of discipline policy effectiveness is a healthy relationship between school and students as indicated by such variables as principal's leadership styles and student's perceptions of whether or not they are fairly treated. Could this be the perception of F.C.E. students on the issue of Dressing Code? This question will be answer in the course of study.

With the above limitations in mind, we can define the basic functions of discipline policy. The basic functions of discipline policy according to Ben $(2000,37)$ include; informing the leader of the school board of discipline philosophy, placing responsibility for policy enforcement and specifying offences and the type of punishment. This functions are not far from the Dressing Code" in FCE Zaria. The problem has been the way the students perceived this disciplinary policy.

Asaju (2007:4) in his study of student's indiscipline in secondary school in Kaduna State before and after Government takeover of missionary schools; identify the following vices of indiscipline as common among secondary school students. They include examination malpractices, alcoholism, drug abuse, and disrespect for constituted authorities and immoral behaviour, such as sexual immorality, indecent dressing, and prostitution, among others. His study revealed that these disruptive behaviours are not common and very low during the missionary era. But these vices became very common and high after the government took over these schools. Also, moral values were poorly developed in these schools. These problems consequently affected the standard of education in these schools. The study also shows the student's performance in SSCE exams in Kaduna State had being the low performance in the past two decades. The study further shows that the major stakeholders in ensuring child discipline (i.e. family, teacher/school management, religious groups and society) have all failed in performing their roles as an agent of child socialization.

Although, the study was undertaken in secondary schools, the disciplinary situation in these schools cannot be far- fetched and might even be more prevalent in our tertiary institutions, including FCE Zaria. Furthermore, among the identified vices of indiscipline, sexual immorality, indecent dressing, prostitution etc. are more prevalent especially among the female students in the educational institutions in Nigeria.

To stop the increasing rate of indecent dressing among girls in tertiary institutions in Nigeria, many institutions established the "Dressing Code" which not only stipulated the types or form of dressing to be worn in the school, but also the punishment for offenders.

\subsection{Dress Code}

Dress Codes are written and, more often, unwritten rules with regards to clothing. Clothing like other aspects of human physical appearance has a social significance, with different rules and expectations being valid depending on circumstance and occasion.(Wikipedia)

Dress Codes function on certain social occasions and for certain jobs. All military and paramilitary institutions have specified uniforms. Officers are only allowed to dress in mufti when they are not on duty or when situation demands. Other formal organisations also maintain dress codes that are in line with their profession (i.e. bankers, airways, lawyers, doctors, etc).

Also, educational institutions specify certain mode of dressing for their students. In most tertiary institutions in Nigeria, dress codes are maintained to ensure that students maintain certain level of decency in their mode of dressing within the school environment. A Student's style of dress could be reflection of the individual's preference; however, such preferences must be selected within the constraints of reasonable rules and appropriate standards that are consistent with the maintenance of an effective learning atmosphere and good personal hygiene. It is expected that each student's attire and grooming promote a positive, safe and healthy environment for learning. Even though the school authority recognises the fundamental right and freedom of the students, it is the responsibility of the school authority to provide and ensure a safe, orderly and secure 
environment conducive for learning. Thus the formulation and implementation of the Dress Code is pertinent to ensure that the students achieve the best in their learning process.

However, Organisations which seek to maintain standards of modesty have difficulties with sheer and seethrough clothing. Dress Code usually set a lower limit on body covering. However, sometimes it can specify the opposite, especially during night parties.

During wedding, naming ceremony, graduation etc guests dress respectfully. In Nigeria, friends and other guest during festive or other occasions wear the same dress popular non as Anko or 'Aso ebi'. Also, various religious groups have their own forms of dress code expected to be obeyed by members. Some churches in Nigeria do not allowed females to wear trousers, tights, see-through and short skirts or any other clothes that exposes the body. Churches also specify a particular uniform for certain groups within the church e.g. choir, women fellowship e.t.c.

\subsection{Research Design}

\section{Research Methodology}

But for the purpose of the work, the survey method was adopted. To Ndagi (1999:117) Survey method involves large number of persons and it describes population characteristics by the selection of an unbiased sample from the population of the study. It involved using questionnaires and sometimes interview or test to generate data from the sample and generalizing the results of findings from the data on the population from which it was drawn.

\subsection{Population of the Study}

The population of this study comprised of the students of Federal College of Education, Zaria. As at 2010 , the total population of the students was 2000, this include 1400, NCE students and 600 undergraduate students.

\subsection{Sampling Techniques and Sample Size}

In taking sample from the population, $10 \%$ of the population was taken as sample size. The stratified and random sampling techniques were adopted in selecting the sample. The students and the academic staff were stratified according to their schools i.e. School of Sciences, School of Social Sciences, School of Languages, and School of Vocational and Technical Education. School of Education was exempted due to the fact that it serviced all the other Schools. However, the academic staff of the School of Education was included in the sample size. In each of the strata, $20 \mathrm{NCE}$ and 5 undergraduate students were randomly selected. Five academic staff was randomly selected from the five Schools.

Thus, 200 students were randomly selected as sample respondents for the students, while 25 academic staff members were randomly selected from the five Schools in the College. Also, the five senior staff of the Students' Affairs Unit of the College was included in the sample.

Therefore, the sample size for this study was 230 comprising 200 students, 25 academic staff, and 5 staff of Students Affairs Unit. In view of this sample size, 230 questionnaires were drawn and administered on the sampled respondents.

\subsection{Data Collection Instruments}

The data utilized in this study were collected through primary and secondary sources. Primary Data: The primary source of data includes questionnaire, interview and observation.

Questionnaires were drawn and distributed to the three categories of respondents (i.e. student, academic staff, and Staff of Student's Affairs Unit). The questionnaires took the form of open and close ended questions. The interviews cut across the three categories of respondents in this study. Similar issues raised in the questionnaires formed the core of the interviews.

The third instrument for collecting primary data for this study was observation. This research work has to do with physical outlook (dressing) and attitude of the students. The attitudinal dispositions of the students were physically observed in the course of the study. The reactions of the offenders were also observed during the distribution of the questionnaires drawn. Above all, through observation, the researcher was able to identify those who wore indecent dresses.

Secondary data was collected through the examination of textbooks, Journals/Articles, Papers presented at conferences, seminars and workshops, Internet materials and other publications. Major sources of secondary data for the study include the Student manuals and other official publications of F.C.E, Zaria.

\subsection{Method of Data Analysis}

Data collected from the questionnaires were presented in tabular form. The data were analyzed using frequency counts and percentages. Data collected from the interview, observations made and secondary data were descriptively analyzed. The data were used to answer the research questions. 


\section{Data Presentation and Analysis \\ 4.1: Students' perception of the Dress Code}

Table 4.1: Students' perception of the Dress Code

\begin{tabular}{|c|c|c|c|c|c|c|c|c|}
\hline \multirow[t]{2}{*}{ Responses } & \multicolumn{2}{|c|}{ Agree } & \multicolumn{2}{|c|}{ Disagree } & \multicolumn{2}{|c|}{ Undecided } & \multicolumn{2}{|c|}{ Total } \\
\hline & $\mathrm{F}$ & $\mathrm{P}$ & $\mathrm{F}$ & $\mathrm{P}$ & $\mathrm{F}$ & $\mathrm{P}$ & $\mathrm{F}$ & $\mathrm{P}$ \\
\hline $\begin{array}{l}\text { Dresses identified in the Dress Code constitute indecent } \\
\text { dresses }\end{array}$ & 48 & 27 & 116 & 66 & 12 & 7 & 176 & 100 \\
\hline Dress Code as part of learning process & 67 & 38 & 92 & 52 & 18 & 10 & 176 & 100 \\
\hline Dress Code as the training of mind and personality & 67 & 38 & 92 & 52 & 18 & 10 & 176 & 100 \\
\hline Dress Code as a form of building good character & 70 & 40 & 92 & 52 & 14 & 8 & 176 & 100 \\
\hline $\begin{array}{l}\text { Dress Code impedes on students' Fundamental Rights } \\
\text { and Freedom of Choice in school }\end{array}$ & 114 & 65 & 56 & 32 & 5 & 3 & 176 & 100 \\
\hline Dress Code impedes on students' social life in school & 113 & 64 & 60 & 34 & 3 & 2 & 176 & 100 \\
\hline Indecent dressing is an act of indiscipline & 74 & 42 & 92 & 52 & 10 & 6 & 176 & 100 \\
\hline Indecent dressing Constitute a bad character & 70 & 40 & 99 & 56 & 7 & 4 & 176 & 100 \\
\hline Indecent dressing Constitute immoral act & 70 & 40 & 99 & 56 & 7 & 4 & 176 & 100 \\
\hline Indecent dressing Constitute unlearned behaviour & 70 & 40 & 88 & 50 & 18 & 10 & 176 & 100 \\
\hline Indecent dressing Constitute a bad model & 74 & 42 & 95 & 54 & 7 & 4 & 176 & 100 \\
\hline
\end{tabular}

Source: Survey by the Researcher, 2010

The students' opinions were further sought on whether the dresses identified in the Dress Code were indecent. As contained in Table 4.1 above, $73 \%$ which constituted the majority of the respondents were of the view that the dresses identified in the Dress Code do not constitute indecent dresses. $27 \%$ of them were in affirmative that those dresses were decent, while $7 \%$ of them were undecided.

It could be deduced from the above responses that majority of the students of Federal College of Education, Zaria do not adhere to the Dress Code because a large proportion of them do not see the dresses identified in the Dress Code as indecent dresses.

The Dress Code was seen as a part of the learning process, training of personality and building good character, especially in Teachers Training College like FCE, Zaria. The responses in Table 4.1 above shows an overwhelming agreement by the respondents that the Dress Code was not part of the learning process, $38 \%$ of them affirmed that the Dress Code was part of the learning process. 38\% of them were in affirmative that the Dress Code was a tool for training of the mind and personality, while $52 \%$ of them which constitute the majority had the contrary view. $10 \%$ of them were undecided.

$40 \%$ of the respondents believed the Dress Code was a means of inculcating and building of good character in the students of the College. $52 \%$ of them which constituted the majority were of the contrary view, while $8 \%$ of them were undecided.

The responses as contained in Table 4.1 above implied that majority of the students of the College do not see the Dress Code as a learning process, training of human personality and a means for instilling good character in them.

On the negative side, the respondents' opinions were sought on whether the Dress Code constitutes a barrier to their Fundamental Human Rights and Freedom as well as their social lives. The responses in Table 4.4 above indicated that 65 percent of the respondents believed that the Dress Code was an infringement on their Fundamental Human Rights and Freedom of Choice. 32 percent of them were of the contrary view, while 3\% of them were undecided. 64 percent which constitute the majority of the respondents were also the opinion that the Dress Code impede on their social life on the campus and these responses constitutes the majority. 34 percent of them however, do not see the Dress Code as an impediment to their social life on the campus, while $2 \%$ of them were undecided.

The above responses vividly implied that majority of the students saw the enforcement of the Dress Code as an infringement or violation of their rights and freedom as well as their social life on campus.

Furthermore on students' perception of the Dress Code, $42 \%$ of the respondents affirmed that indecent dressing by students of the College was an act of indiscipline. Majority (52\%) of the respondents disagreed that students who wore those dresses itemized in the Dress Code committed an act of indiscipline, while 6\% of them were undecided. Similarly, $40 \%$ were also of the opinion that indecent dressing by students of the College constitutes a bad character exhibited by the person wearing them. $56 \%$ of them who were the majority disagreed, while $4 \%$ of them were undecided. (40\%) of the respondents also agreed that students who wore those dresses contained in the College Dress Code exhibited an immoral act. majority of them (56\%) disagree on this notion, while $10 \%$ were undecided. Indecent dressing also implies an unlearned behaviour or character. This was attested to by $50 \%$ of the respondents which constitutes the majority. $30 \%$ of the respondents did not see it as such, while $4 \%$ of them were undecided. Finally in the table, majority (54\%) of the respondents disagreed that the perpetuators 
of indecent dressing serves as bad models to others. $42 \%$ of them agreed to this fact, while $6 \%$ of the respondents were undecided.

Based on the responses and findings in Table 4.1 above, the second question that "what were the perceptions of the students of the Dress Code?" is hereby answered

\subsection{Reasons for the students' perception of the Dress Code}

The students were asked what could inform the basis for their perception of the Dress Code. Could it be their family background, religion or culture, or the environment they found themselves? The respondents' opinions were further sought on whether the Dress Code was in tandem with their family, religion and societal values. Their responses were tabulated below.

Table 4.2 Dress Code in consonance with family, religion and societal values

\begin{tabular}{|l|l|l|l|l|l|l|l|l|l|}
\hline Responses & \multicolumn{2}{|l|}{ Agree } & \multicolumn{2}{|l|}{ Disagree } & \multicolumn{2}{|l|}{ Undecided } & \multicolumn{2}{|l|}{ Total } \\
\hline & F & P & F & P & F & P & F & P \\
\hline $\begin{array}{l}\text { Dress Code is in tandem with my } \\
\text { family values }\end{array}$ & 109 & 62 & 53 & 30 & 14 & 8 & 176 & 100 \\
\hline $\begin{array}{l}\text { Dress Code is in tandem with my } \\
\text { religious value }\end{array}$ & 141 & 80 & 23 & 13 & 12 & 7 & 176 & 100 \\
\hline $\begin{array}{l}\text { Dress Code is in tandem with my } \\
\text { societal value }\end{array}$ & 114 & 65 & 53 & 30 & 9 & 5 & 176 & 100 \\
\hline
\end{tabular}

Source: Survey by the researcher, 2010

As indicated in Table 4.11 above, majority of the respondents (students) affirmed that the Dress Code was in consonance with their family, religion and societal values. A detailed analysis of the table shows that majority of the respondents (62\%) agreed that the Dress Code was in tandem with their family value. $30 \%$ of them were of the contrary view, while $8 \%$ of them were undecided. On religious values, 80 percent which constitutes the majority of the respondents asserted that their religious belief and value were in consonance with the Dress Code. $13 \%$ of them were of the contrary view, while $7 \%$ of the respondents were undecided. Majority of the respondents, $(65 \%)$ also agreed that their societal/cultural values do not support the wearing of dresses stipulated in the Dress Code. 30\% of them said their culture does not disallowed such dresses, while 5\% of them were undecided.

\subsection{Reasons why student wear the dresses itemize in the Dress Code in the College}

The respondents were asked why they wear these dresses, despite the fact that some of them were not allowed to wear it at home and it was against their cultural and religious values. Their responses indicated that some of them wear the dresses itemized in the Dress Code because they want to have a sense of belonging. Some of them said they wore those dresses because it makes them smart. Some of the respondents also asserted that they wear the dresses because their friends do so and others said they just love wearing them. It could be further adduced from the above that majority of the students who wear indecent dresses are deviating.

The findings base on the responses as contained in Table 4.2 above provide answer to the third research question.

In view of the responses in table 1and 2, the first hypothesis that "there is no relationship between the family background of the students and their disposition to the College Dress Code" is hereby accepted.

\subsection{Discussions and Findings}

Based on the responses in Table 1and 2, it was obvious that the students were aware of the Dress Code. Interview with some staff of the Student's Affairs Unit vividly revealed that there was enough publicity through Circular placed on Notice Boards in strategic areas of the College. The Student Affairs officials affirmed that any student who claimed ignorant of the Dress Code was been mischievous and not honest. However despite the level of awareness of the Dress Code, majority of the students do not adhere to the Dress Code. They also disagreed that the dresses identified in the Dress Code were indecent dresses. Furthermore, majority of the students disagreed that the Dress Code constitutes part of the learning process, the training of mind and personality, as well as a form of building good character. Majority of the respondents also disagreed that wearing of the dresses indicated in the Dress Code constituted an act of indiscipline, bad character, immoral act and unlearned behaviour. They also affirmed that the implementation of the Dress Code in the College was an impediment to their Fundamental Human Rights, Freedom of Choice and freedom to socialize in school.

Majority of the students also agreed that the Dress Code was in agreement with their family, religion, and societal values. Majority of them also agreed that they wore these dresses at home and their parents or guardian never stopped them. Majority of the respondents also wear these dresses in the College despite the enforcement of the Dress Code. The major reasons why they wear such dresses in the College include, having a 
sense of belonging, making them look smart, because their friends wear them, and lastly because they just love wearing them.

On the consequences of indecent dressing by students of the College, majority of the respondents agreed to the fact that one's mode of dressing reflects his/her personality. The female students could also be a victim of sexual harassment. They agreed that teachers should be a good role model in their mode of dressing.

\subsection{Conclusion}

\section{Conclusion and Recommendations}

The Dress Code constitutes one of the rules and regulations guiding the conducts of the students in the campus. Its intention is to ensure that every student dress moderately in compliance with the teaching profession and societal values of the environment. It is expected that every student abides by it. But despite the wide publicity, strict implementation to the Dress Code; the punishment stipulated to be meted out to offenders as well as other implications associated with disobeying the Code, many students still have a wrong perception of the Dress Code. Thus they violate it with impunity.I

\subsection{Recommendation}

Therefore, the study recommends the followings

$>$ The College should re-orient the students on some of their beliefs that were contrary to the ethics of teaching profession.

> The College should create more awareness on Dress Code through the use of bill boards, visible posters in strategic areas within the premises. The bill board should show pictures of students wearing decent dresses.

$>$ Since the Dress Code constitutes one of the rules and regulations guiding the conducts of the students in the College, all those responsible for enforcing the Dress Code in the College should be allowed to perform their duties without any interference by the management.

$>$ The College management should understand that the entire institution, work as a system. If any of the sub system is mal-functioning it would definitely affect the entire system. Even the sub systems required the support of the others. Thus, management should give utmost support to all the departments and units in the performance of their duties. When students are aware that there is no cordial working relationship among staff, they tend to perpetuate high rate indiscipline.

$>$ The College management should rise above sentiments in enforcing the Dress Code. As asserted by Beach (1974), those who obeyed the rule should be rewarded, while those who deviated should be punished.

> Finally, the students should see themselves as role models who will be teachers or leaders of tomorrow. Therefore, they should be conscious of their mode of dressing.

[1]. The Contemporary Longman Dictionary $\left(9^{\text {th }}\right.$ Edition $)$

[2]. Akinmade et.al "Education in Jos Ecclesiastical Province of Northern Nigeria" (Kaduna: Catholic Resource Centre, 1999)

[3]. Federal College of Education (FCE) "Year 2005 Annual Report" Abifas Printing Press, Zaria.

[4]. Federal College of Education (FCE) "Students' Handbook" Federal College of Education, Zaria, Kaduna State

[5]. Preston, P and Zimmirer, T.W Managers for Supervisors (New Jersey: Prentice Hall Inc, 1968).

[6]. Megginson, L.C Personnel Management: A Human Resource Approach (Ontario: Richard. D Irwin, Inc, 1970)

[7]. Haimann, T and Hugert, R Supervision, Concepts and practices of Management (Ohio: South Western Publishing Company, 1974).

[8]. Gottfredson G.D et al Reducing Disorderly Behaviour in middle schools" Baltimow, Maryland: Center for Research and Elementary and Middle Schools. Report No. 37, 1989

[9]. Duke, D.L "School Organization, Leadership and Student Behaviour" In Oliver C.M (2000) Strategies to reduce Students' misbehavior Washington D.C: Office of Education Research and Improvement, US Department of Education, 1984

[10]. Gottfredson: G.D and Denise, G (1989) "Developing Effective organization to reduce school disorder" in Oliver C.M Strategies to reduced students' misbehavior Washington D.C: Office of Education Research and Improvement, US Department of Education, 2000.

[11]. Ben-Yunusa, M Policy: Issues on Curriculum (Zaria: Ahmadu Bello University Press, 2002)

[12]. Asaju, K "The Effects of Government Take-Over of Missionary Schools on students Discipline in Kaduna State" Being a Paper Presented at the Sixth National Conference of the National Association of Educational Planners and Managers, at Ahmadu Bello University, Zaria. Nigeria, 2007

[13]. Ndagi, J.O Essentials of Research Methodology for Educators (Ibadan: University Press PLC, 1999).

[14]. Dress code- Wikipedia, the free encyclopedia. Dress-code. htm Retrieved 2011:11:10

[15]. Beach, D. S Personnel: The Management of people at work (New York: Macmillan Publishing Company, 1975) 